\title{
Probing Institutional Quality Through Ethnic Diversity, Income Inequality and Public Spending
}

\author{
Ghulam Rasool Madni ${ }^{1}$
}

Accepted: 10 May 2018 / Published online: 16 May 2018

(C) The Author(s) 2018

\begin{abstract}
Institutions play a vital role for smooth and sustained functioning of economies as well as to excel the living standard of economic agents but there is no consensus upon factors explaining the institutional quality. This study is an attempt of how ethnic diversity, income inequality and public spending are encompassed to affect the institutional quality, illustrated by the example of a developing country, Pakistan, applying ARDL approach covering time span of 1984-2015. It is found that ethnic diversity and income inequality are associated with deterioration of institutions and public spending is likely to improve them. Ethnic diversity has to be managed endogenously to avoid its adverse effects on institutions while there is dire need to squeeze the widening gap between rich and poor. The findings of the study reveal that public spending needs to be contribute more at present for building the institutional quality.
\end{abstract}

Keywords Institutions $\cdot$ Ethnic diversity $\cdot$ Income inequality $\cdot$ Public spending

\section{Introduction}

The institutions comprise both formal rules and informal norms with their enforcement mechanism, structure human interaction. It is now widely accepted that technological change and factors accumulation are not sufficient for economic performance across nations but there appears to lie behind much of these reasons that may cause to boost economic development and growth; for example, at the level of institutions. Several experimental studies (La Porta et al. 2008; Acemoglu and Johnson 2005; Acemoglu et al. 2001; Clague et al. 1999; Knack and Keefer 1995) have shown presence of tight links between development, growth and institutions. Efficient and effective institutions matter for enhancing the investment levels, higher social capital stock of a society, better policies, and effectual

Ghulam Rasool Madni

ghulam.rasool@econ.uol.edu.pk

1 The University of Lahore, Lahore, Pakistan 
control on social violence, conflicts and ethnic diversity (North 1990, 1994; Aron 2000; Chu 2001; Dollar and Kray 2002; Rodrik et al. 2004; World Bank 2002; Jutting 2003).

It is much controversial in literature to measure the institutional quality itself and knowing their formational factors in a country. Institutional building is result of interdependencies and interaction of economic, social, geographic and political factors (Sokoloff and Engerman 2000; Acemoglu et al. 2001; Straub 2000; La Porta et al. 2008; Knack and Azfar 2000).

The coexistence of multi cultures in societies is at front in academic debate. Cultural pluralism and diversity like ethnic, religious, politics, psychology etc. have posed some serious questions needed to be resolved. Ethnic diversity is groups of people with different culture, races, nature and religion. The literature about impact of ethnic diversity for institutions is at its infancy and requires a special attention to be explored further. Ethnic polarization may have adverse effects on institutional deterioration in many situations (Alesina et al. 1999). Easterly (2001) argued that groups having linguistically distinctions have dissimilar choices for language to be used in schools. If there is common language in schools but still every group have more value if medium of teaching is in their ethnic tongue. In the same way, different income groups show their interest in those institutions which function for their gains. For example, large organizations have easy access to credit facilities as compared with new entrants in the market.

Hoff and Stiglitz (2004) and Sonin (2003) developed analytical models to explore the effectiveness of economic conditions for institutional quality. They argue that equal income distribution provides foundational pillar to construct the good institutions and weak institutions cause to increase the rent seeking over public resources. Low quality institutions were observed where increase in inequality persists. Chong and Calderon (2000) also proved the negative significance of income inequality for institutional quality. The model of study shows that when a group of society feels economic deprivation then it has less respect for the institutions of the country. Moreover, high quality institutions and low income inequality put the economy on the path of sustainability and prosperity.

Recently, role of public spending for institutional development got a striking attention of the policymakers and researchers of the subject, especially after financial crisis of 2008. Endogenous and Keynesian growth theories proved the significant role of fiscal policy for economic development of an economy. The public spending may be helpful to raise the economic growth by developing the institutions like maintaining the law and order, managing ethnic diversity, protection of property rights, control over corruption, provision of public goods, and other social services that may lead to improve the aggregate demand and sustainability of economic growth. In addition, the productive projects of government or its interaction with local or foreign investors has a positive effect on growth.

Institutional performance and their development remained very poor for Pakistan, especially after the decade of 1980s. According to Hassan (2002), there was degeneration of institutions in the country over the past three decades, and the decade of 1990s brought a great degradation of institutions. Poor governance of country excluded the poor people of society in process of decision making and malfunctioning of institutions caused the failure of benefits of rising per capita income to the poor. The increased poverty further weakened the quality of institutions and poor are trapped in the vicious circle of poverty. The poor institutions lead to increase the transactions costs of economy so living standard of public could not be improved in spite of much public spending. This deterioration of institutions requires further investigation of those factors which are responsible for institutional quality.

The preceding discussion elucidates that ethnic diversity, income inequality, public spending could have an impact on institutional quality. The unrest among multicultural 
society could be overcome through public spending to decrease income inequality so sense of deprivation would eradicate and respect for institutions is expected to be restored. On the other side, earlier studies pay attention to address the question is that how institutional framework and institutions explain the economic development and performance of economies. But what does determine institutional quality in an economy is a controversial topic in literature, lying at its infancy. This paper is an attempt to explore the impact of social and economic aspects like ethnic diversity, public spending, and income inequality for institutional development by considering time series data from 1984 to 2015 for a developing economy, Pakistan.

\section{Literature Review}

The significance of institutional role for economic development cannot be negated due to immense theoretical and empirical studies. But there is controversy in literature about the factors explaining institutional quality of an economy. Josifidis et al. (2017) empirically examined the impacts of changes in institutional quality on income inequalities in developed countries for the last two decades. It is argued that different interests of social groups are contributing to deteriorate income inequalities but their affects are not properly analyzed because distributional impacts of innovative disruptions are ignored. The study selected the sample of 21 OECD countries and found that effectiveness of elitization is higher than unionization on income redistribution while both are less pronounced in comparison with institutional change in these countries. It is highlighted that institutional inertia (slow changes in institutional environment) is partially responsible for high income inequalities and insufficient redistribution.

Kotschy and Sunde (2017) provided an evidence by support of a variety of panel data models proving that quality of economic institutions is not only dependent on income inequality and democracy but their interaction also matters for institutions. This study has contrary view regarding the effectiveness of democracy on quality of economic institutions to reduce the income inequality. It is argued that democracy is not necessary to form high quality economic institutions while rise in income inequality erodes the quality of institutions in spite of democracy, "up to the point that democracies appear not to be able to implement good institutional environments if inequality is too high."

Law et al. (2014) examined the relationship among institutional quality, income inequality and financial development covering the time span over 1985-2010 for eighty one countries. By applying the threshold regression approach, it is concluded that threshold level of institutional quality matters to explain the relationship between income inequality and financial development. A certain threshold level of institutional quality is required for the effectiveness of financial development to reduce income inequality in sample countries while financial development would be in vain to reduce income inequality in nonexistence of threshold level of institutional quality. It is suggested that sound institutional structure has embedded ability to overcome the problem of income inequality with flourishing the financial sphere of economies.

Chang $(2002,2011)$ argued that developing countries should learn from the adopted model of developed countries. His historical analysis reveals the interventionist policies of now developed countries to grow but their institutions were not developed properly during the early stages of development. Contrary, now developing countries are focusing on better institutions and employing less protectionist policies so development process is going to be 
slow. He concludes about the institutions of developed countries as, "Current framework in effect 'kicks away the ladder' the now developed countries used to achieve wealth and prosperity". The author puts the examples of USA, UK, Germany and France. But a careful analysis convinces us that modern economies are much different and complex as compared with economies of 18th and 19th century. Now free flow of capital in form of financial institutions and central banking, migration of labor and transportation of goods require efficient institutional structure. Moreover, Chang perceives the slow growth of developing countries as failure of policies but it seems opposite in actual. These developing countries are mature economies due to many reasons. By avoiding protectionist policies, developing economies have a great benefit because firms of developed economies outsource in these regions to take cost advantages and China, India are exemplary cases as recipient of outsourcing. This transfer of knowledge is also beneficial for infant industry to grow and prosper by getting outcome of that research carried out in developed countries since decades. Moreover, developing economies could not be developed in isolation due to complex interconnections of all economies as a result of globalization process so institutions matter for development and growth. It can be agreed with Chang that establishment of good institutions in short period of time is much difficult task. It can be argues that developing countries should develop their economic institutions at first. Once economic development is gained then other efficient and expensive institutions may be demanded.

Chang (2007) bridges a new level of analysis between political economy of institutions and history which demolish the conventional wisdom and establish new set of standards for future research about institutions. The importance of institutions for economic development is also recognized by international forums like IMF and World Bank. But there are important literature gaps required to be filled for comprehensive analysis of institutions and their efficacy for economic development. A wide range of real life institutions like social, financial, corporate, political, fiscal, bureaucratic, legal, industrial should be considered for better understanding of functioning of economies. A simple formula is unable to measure the institutional development but a complex combination of all prevailing institutions in an economy could be utilized for helpful policy ideas based on sophisticated theoretical views.

Redek and Susjan (2005) conducted a panel analysis covering the data of twenty four transitional countries for the period of 1995 to 2002 to investigate the role of institutions for economic growth and performance. The data set of index for institutions is gained from "Heritage Foundation". The economic growth is treated as dependent variable while domestic investment, budget deficit and foreign direct investment (FDI) and inflation are treated as exogenous variables. The model without institutions presented poor estimations. But after inclusion of institutional variables in the model, the estimated model explained the $51 \%$ variations in economic growth by the institutional variables and signs of variables were according to expectations. Additionally, it was concluded that economic growth is affecting by not only the current institutional quality but also affected by the past trend of variables reflecting the institutional quality. The national output of the economies is directly linked with the quality of institutions prevailing in these economies. The institutional quality and speed of reforms are essential features to explain diverse economic outcomes in these countries.

Alesina et al. (2002) and La Porta et al. (1999) showed that ethnic diversity has negative correlation with infrastructure quality, educational attainment while positive correlation with infant mortality. Assane and Grammy (2010) estimated a regression model by considering a sample of 110 economies along with sub-samples representing economies with diverse level of development. The variables are labor force growth, physical capital 
formation, human capital formation, economic freedom. Two variables are used to represent the institutional framework. One is the institutional efficiency which is measured as un-weighted averages of nine indicators of government performance. The outcomes show that institutional quality will be higher if institutional efficiency is higher. The second variable of institutional quality is used political risk ratings measured by the "International Country Risk Guide". The estimated results of the model indicate institutional variables are significant to explain the economic growth for both medium developed and less developed countries. Moreover, institutional quality and institutional framework are also very significant for the process of economic development. By concluding, the author suggests that model with inclusion of institutional variables are stronger in explaining the economic growth as compared with exclusion of institutional variables.

Hall and Jones (1999) postulated one of first empirical research establishing the relation between economic performance and institutions. Social infrastructure is considered as institutional variable which was defined as "the institutions and government policies that determine the economic environment within which individuals accumulate skills, and firms accumulate capital and produce output." They mentioned the relation between the provision of protection to private productive units from confiscatory diversion and institutions. Yielding that a perfect measurement of social infrastructures is not in rehearsal, they choice a proxy gained by pooling two indexes: "an index of government anti-diversion policies" and "an index of openness to international trade". On the other hand, a fundamental basis to measure the institutions was provided in this study and adopted methodology to measure institutional variables was used in many studies to know the relation between institutions and economic performance in many studies later on.

Glaeser et al. (1995) explored the effect of racial fragmentation on growth of US cities having sample of 1960-1990 but did not find any relationship between two variables. The finding of study regarding racial composition reveals that "in cities with large nonwhite communities segregation is positively correlated with population growth." On the other side, Rappaport (1999) proved that more racial fragmentation affects the growth in negative way.

By concluding, institutions matter for economic performance due to their diverse impacts but what determines the institutional quality is a question required to be answer in more depth. A brief review of literature motivates to explore the social and economic factors like ethnic diversity, income inequality and public spending to improve the institutional quality with reference to Pakistan and this study is intended to fill this gap.

\section{Theoretical Framework}

A game theoretic model is developed to determine the impact of ethnic diversity, income inequality and public spending for institutional performance in an economy. It is assumed that there are two rational agents in the economy, want to maximize their utility. The utility of government depends upon the tax rate and a policy position about social matters like ethnic diversity and income inequality. Its utility will increase by increasing the tax rate and will decrease if it is farther from policy position. On the other side, the tax rate and selected policy position will also affect the utility of citizens. The citizens owning the factors of production will make production decision on the basis of tax rate. Their utility will increase by increasing the level of output which will be net of production costs and taxes. So this utility maximization can be shown as; 
For government

$$
\begin{gathered}
\operatorname{Max} \quad U^{G}\left[T f(Y), N R,-\left(P-P^{+}\right)\right] \\
(T, N R, P) \\
\text { S.to } \quad T f(Y)+N R \leq K \\
\\
U^{c} \geq \underline{U^{c}}
\end{gathered}
$$

For citizens

$$
\text { Max } U^{c}\left[(1-T) f(Y)-W . Y,-\left(P-P^{-}\right)^{2}\right]
$$

where $U^{G}=$ Government Utility, $U^{c}=$ Citizens Utility, $\underline{U}^{c}=$ Minimum Tolerable Utility of Population, $P=$ Chosen Policy by Government, $P^{+}=$Preferred Policy Position by Government, $P^{-}=$Preferred Policy Position by Citizens, $T=$ Tax Rate, $N R=$ Non Tax Revenues, $K=$ Maximum amount of Collected Revenues, $F(Y)=$ Output, $Y=$ Factors of Production, $W=$ Average Cost of Production.

Nash equilibrium is the solution of the problem which states that decisions of government and citizens is best response against each other. Given P and T, citizens decide how much factors of production has to hire in response of government's policy. First order condition will be;

$$
(1-T) f^{\prime}(Y)=W
$$

and solution is;

$$
Y^{*}(T, P)
$$

Government maximizes against the response of production by citizens by knowing $\mathrm{Y}^{*}(\mathrm{~T}$, P). Government's maximization problem will be;

$$
\left.\operatorname{Max} U^{G}\left[T f(Y), N R,-\left(P-P^{+}\right)\right\rfloor+\lambda_{1}+\left\lfloor(1-T) f^{\prime}(Y)-W\right\rfloor+\lambda_{2}\left(U^{c}-\underline{U^{c}}\right)+\lambda_{3} \mid K-T f(Y)-N R\right\rfloor
$$

First order conditions are as follows;

$$
\begin{gathered}
\left(U^{G}\right)_{1} f(Y)-\lambda_{1} f^{\prime}(Y)-\lambda_{2}\left(U^{c}\right)_{1} f(Y)-\lambda_{3} f(Y)=0 \text { w.r.t. " } T \text { " } \\
\left(U^{G}\right)_{2}-\lambda_{3}=0 \text { w.r.t. " } N R " \\
-2\left(U^{G}\right)_{3}\left(P-P^{+}\right)-2 \lambda_{2}\left(U^{c}\right)_{2}(P-P)^{-}=0 \text { w.r.t. " } P \text { " } \\
\left(U^{G}\right)_{1} T f^{\prime}(Y)+\lambda_{1}(1-T) f^{\prime \prime}(Y)+\lambda_{2}\left(U^{c}\right)_{1}\left[(1-T) f^{\prime}(Y)-W\right]-\lambda_{3} T f^{\prime}(Y)=0 \text { w.r.t. " } X \text { " } \\
(1-T) f^{\prime}(Y)-W=0 \text { w.r.t. " } \lambda_{1} " \\
\lambda_{2}\left(U^{c}-\underline{U^{c}}\right)=0 \text { w.r.t. " } \lambda_{2} \text { " } \\
\lambda_{3}[K-T f(Y)-N R]=0 \text { w.r.t. " } \lambda_{3} \text { " }
\end{gathered}
$$

where (4.6) and (4.7) follow Kuhn-Tucker condition for inequality constraints.

From (4.2)

$$
\lambda_{3}=\left(U^{G}\right)_{2}>0
$$


From (4.3)

$$
\lambda_{2}=\left[\left(U^{G}\right)_{3}\left(P-P^{+}\right)\right] /\left[\left(U^{c}\right)_{2}(P-P)^{-}\right]>0
$$

(4.8) and (4.9) show that inequality constraints are binding by (4.6) and (4.7) in equilibrium i.e.

$$
\begin{gathered}
U^{c}=\underline{U^{c}} \\
T f(Y)+N R=K
\end{gathered}
$$

Taking the total derivative of (5) after substituting its values, we get;

$$
\begin{aligned}
& -\left(U^{c}\right)_{1} f\left(Y^{*}\right) d T-2\left(U^{c}\right)_{2}\left(P-P^{-}\right) d\left(P-P^{-}\right)=0 \\
& \Rightarrow d\left(P-P^{-}\right) / d T=-\left(U^{c}\right)_{1} f\left(Y^{*}\right) / 2\left(U^{c}\right)_{2}\left(P-P^{-}\right)<0 \\
& \Rightarrow d\left(P-P^{-}\right) / f\left(Y^{*}\right) d T=-\left(U^{c}\right)_{1} / 2\left(U^{c}\right)_{2}\left(P-P^{-}\right)<0
\end{aligned}
$$

Derived Eq. (7) implies the comparative static results for change in institutions due to changes in taxes and adopted policies. These revenues are utilized for government expenditures so revenues can be replaced by government expenditures and managing the ethnic diversity, decrease in income inequality may represent the policy options of government. The derived model will be as follows;

$$
I N S T=f(G E X P, E T H D, I N D I S, C T R L)
$$

where INST, GEXP, ETHD, INDIS, CTRL represent Institutional Quality, Government Expenditures, Ethnic Diversity, Income inequality, and other control variables respectively.

\section{Data and Variables}

Andrews (2008) warns about the danger of isomorphism with indicators, which move away from a deterministic concept of desirable development based n idyllic image of government in developed countries. The author argues that previously developed models and indicators have little capacity of consistency and not suitable for developmental dialogue so "A framework is needed before we measure government effectiveness or propose specific models of what government should look like. Given the evidence of multiple states of development, the idea of a one best-way model actually seems very problematic."

In spite of above reservations for indicators to measure a variable, this study utilized the best available data set for institutional quality. The data set of institutional quality is based on the compilation of different institutional measures from ICRG (International Country Risk Guide), organized in twelve clusters namely as Bureaucratic Quality, Democratic Accountability, Ethnic Tension, Rule of Law, Religion in Politics, Military in Politics, Corruption, Government Stability, External Conflict, Internal Conflict, Investment Profile and Socioeconomic Condition. All of these variables range from 0 to 10. A higher score means higher condition and vice versa. By considering all these variables, an institutional quality index is developed by PCA (Principal Components Analysis). PCA is a statistical technique which uses an orthogonal transformation to alter a group of observations having a possible correlation of variables into an array of uncorrelated linear variables. The time span of data for this study is from 1984 to 2015. 
Ethnicity diversity is amalgamation of many attributes in a territory such as caste, race, minority, groups, class, immigrants and other nationals. The following formula developed by Alesina et al. (2002) is used to calculate the ethnic diversity in this study.

$$
F_{R A C T_{j}}=1-\sum_{i=1}^{N} S_{i j}^{2}
$$

whereas $S_{i j}$ is the share of group $\mathrm{i},(\mathrm{i}=1 \ldots \mathrm{N})$ in the country $\mathrm{j}$ (means Pakistan). The value lies between 0 and 1 where 0 represents the homogenous and 1 for heterogeneous situation. The data of ethnicity diversity was taken from the Database of Cline Center for Democracy.

Government spending is an important factor that may improve or deteriorate the institutional quality. The government spending plays a vital role to increase the living standard of people by providing better sanitation, housing, infrastructure, communication, health services, educational institutions, food security and agricultural as well as industrial productivity. According to Hobbes (1651), "government's role in the development process of the economy is vital by providing law and order services including provision of property rights and effective court system for justice." Government expenditures are treated as a percentage of GDP. Public spending affects legitimacy and efficiency of institutions so it can be perceived as a crucial variable explaining the behavior of institutions. Government spending is not only a necessary source for high quality institutions in the country but also permits consolidation of social contracts that ensures and develops a more trustworthy relation between citizens and state. Resultantly, higher accountability and transparency will lead to creation of high quality institutions (Moore 2004; Tilly 1992).

According to Alonso and Garcimartin (2010), "Income distribution also plays an important role for explaining the quality of institutions in the state. It supposedly influences both institutional legitimacy and predictability. Firstly, because a strong inequality causes divergent interests among different social groups, which, in turn, leads to conflicts, socio-political instability and insecurity. Secondly, inequality facilitates that institutions remain captured by groups of power, whose actions are orientated to particular interests rather than to the common good. Thirdly, it diminishes social agents' disposition to cooperative action and favors corruption and rent-seeking activities. Also this relationship is supported by previous studies (Alesina and Rodrik 1994; Alesina and Perotti 1996; Easterly 2001). This variable is measured by GINI coefficient.

International openness is also a factor that can encourage institutional quality. It is related to the dynamic efficiency of institutions. Firstly, it creates a more dynamic, sophisticated and demanding environment, which fuels a larger demand for good institutions. Secondly, international openness encourages a more competitive environment; therefore it can hinder rent-seeking activities, corruption and nepotism. Finally, openness can facilitate learning processes and good practices imitation from other countries experience. References to this variable are abundant, though with not totally coincidental results. For example, Rodrik et al. (2004), Rigobon and Rodrik (2004), Islam and Montenegro (2002) confirm that openness has a positive impact on institutional quality.

Education is also considered as a determinant of institutional quality. It is a variable related to institutions dynamic efficiency. A more educated population demands more transparent and dynamic institutions and permits to build them. As an exception, the work of Alesina and Perotti (1996), which confirms the positive impact of education on 
institutional quality, must be pointed out. Also, in the literature on corruption, the education effect has been detected in work of Evans and Rauch (2000)." Primary and secondary enrolment as a percentage of population is considered as a proxy for education.

\section{Empirical Analysis and Economic Implications}

To find the unit root and order of integration, ADF test is applied to all variables. The results indicate that some variables are stationary at level while others are stationary at first difference. The estimated results of the test are reported in the following Table 1.

The estimated values indicate order of integration of each variable of model. It is obvious that order of integration is different of variables. Some variables are integrated at level while others are integrated at first difference. If variables have different integrating order, then ARDL approach is appropriate to find the long and short run dynamics of variables.

After finding the integrating order of variables, ARDL bounds testing approach to cointegration is used to check the long run relationship between variables. The lag length of variables is obtained from "unrestricted vector autoregressive" (VAR) model via "Schwartz Bayesian Criterion". To find presence of long run relation, F statistics values are calculated after determining the integration order of variables. The value of F-statistic is 6.13 while "critical Bound values" are (2.131-3.250) at 10\% level of significance, (2.476-3.646) at $5 \%$ level of significance and (3.267-4.540) at $1 \%$ level of significance. It can be concluded that long run relation persists among variables. The lag length of variables is obtained where minimum value of Schwartz Bayesian criterion exists.

Now ARDL approach is applied to find long and short run coefficients of variables. The ARDL form of equation will be as follows;

$$
\begin{aligned}
\Delta \mathrm{INST}= & \alpha_{0}+\sum_{i=0}^{n} \alpha_{1} \Delta \mathrm{INST}_{\mathrm{t}-i}+\sum_{i=0}^{n} \alpha_{2} \Delta \mathrm{GEXP}_{\mathrm{t}-i}+\sum_{i=0}^{n} \alpha_{3} \Delta \mathrm{INDIS}_{\mathrm{t}-i} \\
& +\sum_{i=0}^{n} \alpha_{4} \Delta \mathrm{EDU}_{\mathrm{t}-i}+\sum_{i=0}^{n} \alpha_{5} \Delta \mathrm{OPEN}_{t-i i} \\
& +\sum_{i=0}^{n} \alpha_{6} \Delta \mathrm{ETHD}_{\mathrm{t}-i}+\beta_{1} I N S T_{\mathrm{t}-1}+\beta_{2} G E X P_{\mathrm{t}-1} \\
& +\beta_{3} I N D I S_{\mathrm{t}-1}+\beta_{4} E D U_{\mathrm{t}-1}+\beta_{5} \text { ETHD }_{\mathrm{t}-1}+\varepsilon_{t}
\end{aligned}
$$

\begin{tabular}{|c|c|c|c|c|}
\hline \multirow[t]{2}{*}{ Variable } & \multicolumn{2}{|l|}{ Level } & \multicolumn{2}{|l|}{ 1st Diff } \\
\hline & Intercept & Trend and intercept & Intercept & Trend and intercept \\
\hline INST & -1.73 & -1.84 & $-4.71 *$ & $-4.63 *$ \\
\hline ETHD & $-22.59 *$ & $-23.11^{*}$ & $-5.71 *$ & $-4.86^{*}$ \\
\hline GEXP & -1.69 & -2.28 & $-7.97 *$ & $-7.85^{*}$ \\
\hline INDIS & $-1.12^{*}$ & $-1.95 *$ & $-5.36^{*}$ & $-5.94 *$ \\
\hline EDUC & -0.88 & $-4.24 *$ & $-5.66^{*}$ & $-5.55^{*}$ \\
\hline OPEN & $-2.52 * * *$ & $-2.72 * * *$ & $-6.43^{*}$ & $-6.24^{*}$ \\
\hline
\end{tabular}

Table 1 Unit root tests results (augmented Dicky Fuller test)

$*$, ** and $* * *$ shows significance at 1,5 and $10 \%$ level respectively 
Table 2 Estimated long run coefficients

\begin{tabular}{lllll}
\hline Dependent variable INST & \multicolumn{2}{l}{ ARDL technique } & & \\
\cline { 2 - 5 } Independent variables & Coefficient & Stand. error & t-Statistics & Prob. \\
\hline GEXP & $0.15^{* * *}$ & 0.085 & 1.75 & 0.09 \\
ETHD & -0.33 & 0.13 & -2.46 & 0.01 \\
INDIS & $-0.70^{*}$ & 0.25 & -2.80 & 0.00 \\
EDUC & $0.39^{* *}$ & 0.18 & 2.10 & 0.04 \\
OPEN & 0.14 & 0.07 & 1.80 & 0.08 \\
\hline
\end{tabular}

$\mathrm{R}^{2}=0.92$

Adjusted $\mathrm{R}^{2}=0.90$

DW-stat $=1.88$

White Heteroscedasticity $=0.81(0.49)$

ARCH Test $=1.64(0.22)$

Serial Correlation LM Test $=0.01(0.90)$

Jarque-Bera Test $=0.34(0.72)$

$*, * *$ and $* * *$ shows significance at 1,5 and $10 \%$ level of significance respectively

The estimated results are reported in following Table 2.

The estimated equation indicates a comparatively high value of $R^{2}(0.92)$, which means that independent variables of model explain a great proportion of institutional quality of the country.

The estimated results reveal that government spending has positive relationship to improve the institutional quality but it contributes very little. The results show that $1 \%$ increase in government spending will improve the quality of institutions by $0.15 \%$. It may be argued that many categories of government expenditure are not public oriented while government spending is necessary to build high quality institutions, and it produces a more direct relation between state and citizens. According to findings of Moore (2004) and Tilly (1992), government spending is an essential variable explaining the quality of institutions in a country. Government spending is not only a necessary source for high quality institutions in the country but also permits consolidation of social contracts that ensures and develops a more trustworthy relation between citizens and state.

Pakistan is a multi-ethnic federal state of different races, culture, language, religion, regions. Ethnic diversity has important implications to improve the institutional quality. The findings of the study highlight that ethnic diversity is another important and significant variable affecting the institutional quality of the country in negative way and deteriorating the institutions. The benefits of homogeneity can prosper the economy by managing heterogeneity. The peaceful interaction of different people is a critical problem requires to be investigated further. The negative relationship between institutions and ethnic diversity is also proved by Alesina et al. (2003). In contrast, Islam and Montenegro (2002) did not find any association between institutions and ethnic diversity in Latin America and Africa.

The significance of income inequality shows that an equitable income distribution enhances the institutional quality of country. The results show that $1 \%$ increase in income inequality cause to decrease the quality of institutions by $0.7 \%$ because income inequalities cause to lose the confidence of people on institutions. The results are significant at $1 \%$. The findings of this study are also consistent with Alesina and Rodrik (1994), Alesina and 
Perotti (1996), Easterly (2001) and Sokolff-Engerman (2000) hypothesis of greater income inequalities lead to weak instituions.

Regarding education, it affects positively on quality of institutions. The results suggest that educational variable is significant and improvement in education will promote the institutional quality in the country. The findings of the study indicate that $1 \%$ increase in education will lead to promote the institutional quality by $0.39 \%$. It is more important and much significant variable that may enhance the quality of institutions in the country so it should be a more concentrated area to prosper the country. Evans and Rauch (2000), Rodrik et al. (2004) also found the positive impact of education on institutional quality.

International openness is also improving the quality of institutions in Pakistan but it has very lower level of contribution. The estimated results indicate that $1 \%$ increase in international openness will lead to improve the quality of institutions by $0.14 \%$. The impact of trade openness on institutions is controversial in literature. The studies by Rigobon and Rodrik (2004), Rodrik et al. (2004) found a positive but weak relationship between trade openness and institutions. Some studies have contradicted results like Levchenko (2008), Coe and Helpman (1995), Wade (1990) but in case of Pakistan, trade openness is improving the quality of institutions.

\subsection{Error Correction Representation for the ARDL Model}

After estimation of long run relation, now we may find the short run behavior of variables by error correction model. The ECM form of model is following;

$$
\begin{aligned}
\Delta \mathrm{INST} & =\alpha_{0}+\sum_{i=0}^{n} \alpha_{1} \Delta \mathrm{INST}_{\mathrm{t}-i}+\sum_{i=0}^{n} \alpha_{2} \Delta \mathrm{GEXP}_{\mathrm{t}-i}+\sum_{i=0}^{n} \alpha_{3} \Delta \mathrm{INDIS}_{\mathrm{t}-i}+\sum_{i=0}^{n} \alpha_{4} \Delta \mathrm{EDUC}_{\mathrm{t}-i} \\
& +\sum_{i=0}^{n} \alpha_{5} \Delta \mathrm{OPEN}_{\mathrm{t}-i}+\sum_{i=0}^{n} \alpha_{6} \Delta \mathrm{ETHD}_{\mathrm{t}-i}+\mathrm{ECM}_{\mathrm{t}-1}+\varepsilon_{t}
\end{aligned}
$$

Table 3 Estimated short run coefficients

\begin{tabular}{lllll}
\hline Dependent variable INST & \multicolumn{2}{l}{ ARDL technique } & & \\
\cline { 2 - 5 } Independent variables & Coefficient & SE & t-Statistics & Prob \\
\hline$\Delta$ GEXP & 0.20 & 0.41 & 0.49 & 0.63 \\
$\Delta$ ETHD & $-0.11^{* *}$ & 0.04 & -2.47 & 0.02 \\
$\Delta$ INDIS & $-0.40^{*}$ & 0.14 & -2.88 & 0.00 \\
$\Delta$ EDUC & $0.20^{* * *}$ & 0.11 & 1.81 & 0.08 \\
$\Delta$ OPEN & 0.21 & 0.44 & 0.48 & 0.63 \\
ECM $_{\mathrm{t}-1}$ & $-0.28^{* *}$ & 0.14 & -2.02 & 0.05 \\
\hline
\end{tabular}

$\mathrm{R}^{2}=0.88$

Adjusted $\mathrm{R}^{2}=0.85$

DW-stat $=1.93$

Jarque-Bera Test $=0.96(0.50)$

Serial Correlation LM Test $=0.02(0.79)$

White Heteroscedasticity $=0.37(0.39)$

ARCH Test $=0.40(0.43)$

* and ** shows significance at 1 and $5 \%$ level of significance 
Here $\mathrm{ECM}_{\mathrm{t}-1}$ is adjustment parameter. It shows the speed of adjustment while the other parameters represent the short run coefficients. The estimated results are presented in the following Table 3.

The estimated lagged error correction term $\mathrm{ECM}_{\mathrm{t}-1}$ is significant and negative. The significance and negative sign of error correction term shows the presence of long run relation among the variables. The feedback coefficient is -0.28 which shows that $28 \%$ disequilibrium is corrected in short run. In short run, the government expenditures have positive but insignificant impact on quality of institutions in Pakistan while income inequality has significant negative impact on institutions. Education has also positive and significant effect for short term while international openness has positive but insignificant effect on quality of institutions in Pakistan.

\section{Conclusions and Policy Implications}

Institutional development is necessary to promote the economic growth and living standard of the country, has been proven extensively in the literature of new institutional economics. In literature; number of competing hypotheses on what contributes to poor performance of institutional quality has been tested using econometric model. This study explored the factors of institutional quality in Pakistan with special reference to ethnic diversity, income inequality and public spending. Some interesting conclusions are derived from this study.

The estimated results suggest that public spending is also responsible for institutional quality. Government spending is contributing to improve the quality of institutions but it has very little share. There is an ample space to improve the productive efficiency of government spending to have major proportion in improvement of institutions. The public spending establishes a relation of confidence between state and public. Higher the level of confidence builds higher quality of institutions. If government spending is not public oriented, the people prefer to be more corrupt and lose their confidence on institutions that leads to degrade the quality of institutions. To improve the institutional quality of the country, government has to take steps to improve the efficiency of public spending because a major portion of public spending going to be preyed of corruption. According to report of transparency international (2015), in the Corruption Perception Index (PCI), Pakistan stands at $117^{\text {th }}$ position out of 168 countries where $1^{\text {st }}$ position got the Denmark where corruption level is at lowest level while Somalia and North Korea remained at $167^{\text {th }}$ position that reflects highest level of corruption in the world. The public oriented and corruption free expenditures may increase the efficiency of institutional structure of the country.

Secondly, impact of ethnic diversity on institutional quality is controversial in literature. In case of Pakistan, ethnic diversity is playing a fundamental role for deterioration of institutional quality. Ethnic diversity has adverse effects on institutional quality that leads to hamper the economic prosperity so it has to be managed in efficient way by establishing a dense social network needed for growth promotion. Whenever people think that institutions are in favor of them and working for their welfare then they regard the institutions in spite of ethnic polarization. This confidence and trust create the motivation for people to abide by the rules and norms of the society. Ethnic diversity accompanied by weak institutions divides the society posing risks for religious and cultural confliction, civil wars, social tensions, political violence and unrest, corruption—a recipe for underdevelopment. 
Income distribution is an important and significant variable explaining the performance of institutions. In Pakistan, inequality is affecting the quality of institutions badly. When income is not distributed equally, people not abide by the rules of state because they are deprived form luxuries and sometimes, necessities of life. These deprived people are reasons of religious confliction and social unrest in the society. The rich-poor gap can be overcome by creating more employment opportunities and earning sources.

Education is the backbone of a society for development. In Pakistan, education is significantly and positively affecting the quality of institutions. The literate people have more respect for the rules and regulations of the state. Government of Pakistan is trying hard to increase the level of education in the country but there is still much space for improvement. The estimated results also highlight that educational level is also helpful to improve the quality of institutions significantly.

International openness has also positive and significant impact on quality of institutions in Pakistan. If the level of foreign direct investment is higher in the country, there will be more employment opportunities and increased per capita income will improve the living style of people and more sympathy for the country so institutional performance will be better. International openness can be enhanced by reducing the tariffs and barriers on trade.

By concluding, government spending fosters good institutions and high quality institutional framework is expected to be developed in equitable and open economies, with a sound fiscal contract in an educated population. If these conditions are met, then it is possible to build predictable, plausible and efficient institutions.

Overall, results propose that variables leading to explain the institutional quality are in reach of government. Although it is not an easy task but there is room for policies aimed at improving the quality of institutions.

Open Access This article is distributed under the terms of the Creative Commons Attribution 4.0 International License (http://creativecommons.org/licenses/by/4.0/), which permits unrestricted use, distribution, and reproduction in any medium, provided you give appropriate credit to the original author(s) and the source, provide a link to the Creative Commons license, and indicate if changes were made.

\section{References}

Acemoglu, D., \& Johnson, S. (2005). Institutions as a fundamental cause of long-run growth. In: Handbook of economic growth.

Acemoglu, D., Johnson, S., \& Robinson, J. (2001). The colonial origins of comparative development: An empirical investigation. American Economic Review, 91(5), 1369-1401.

Alesina, A., Baqir, R., \& Easterly, W. (1999). Public goods and ethnic divisions. Quarterly Journal of Economics, 114(4), 1243-1284.

Alesina, A., Devleeschauwer, A., Easterly, W., Kurlat, S., \& Wacziarg, R. (2002). Fractionalization. NBER working paper 9411.

Alesina, A., \& Perotti, R. (1996). Income distribution, political instability and investment. European Economic Review, 40(6), 1203-1228.

Alesina, A., \& Rodrik, D. (1994). Distributive politics and economic growth. Quarterly Journal of Economics, 109(2), 465-490.

Alonso, J. A., \& Garcimartin, C. (2010). The determinants of institutional quality. More on the Debate. https:// doi.org/10.1002/jid.1710.

Andrews, M. (2008). The good governance agenda: Beyond indicators without theory. Oxford Development Studies, 36(4), 379-407.

Aron, J. (2000). Growth and institutions: A review of the evidence. World Bank Research Observer, 15(1), 99-135.

Assane, D., \& Grammy, A. (2010). Institutional framework and economic development: International evidence. Applied Economics, 35(17), 1811-1817.

Chang, H. (2002). Breaking the mold-An institutionalist political economy alternative to the neo-liberal theory of the market and the state. Cambridge Journal of Economics, 26(5), 539-559. 
Chang, H. (Ed.). (2007). Institutional change and economic development. UK: United Nations University PressWorld Institute for Development Economics Research (UNU-WIDER), Anthem Press.

Chang, H. (2011). Institutions and economic development: Theory, policy and history. Journal of Institutional Economics., 7(4), 473-498.

Chong, A., \& Calderon, C. (2000). Institutional quality and income distribution. Economic Development and Cultural Change, 48(4), 761-786.

Chu, K. (2001). Collective values, behavioral norms, and rules: Building institutions for economic growth and poverty reduction. WIDER discussion paper 2001/98.

Clague, C., Keefer, P., Knack, S., \& Olson, M. (1999). Contract-intensive money: Contract enforcement, property rights, and economic performance. Journal of Economic Growth, 4(2), 185-211.

Coe, D. T., \& Helpman, E. (1995). International R\&D spillovers. European Economic Review, 39(5), 859-887.

Dollar, D., \& Kray, A. (2002). Institutions, trade, and growth. Paper prepared for the Carnegie Rochester conference series on public policy, http://www.carnegierochester.rochester.edu/April02-pdfs/ITG2.pdf.

Easterly, W. (2001). The middle class consensus and economic development. Journal of Economic Growth, 6(4), 317-335.

Evans, P., \& Rauch, P. (2000). Bureaucratic structure and bureaucratic performance in less developed countries. Journal of Public Economics, 75(1), 49-71.

Glaeser, E. L., Scheinkman, J. A., \& Shlieifer, A. (1995). Economic growth in a cross-section of cities. Journal of Monetary Economics, 36(1), 117-143.

Hall, R. E., \& Jones, C. (1999). Why do some countries produce so much more output per worker than others? Quarterly Journal of Economics, 114(1), 83-116.

Hassan, M. T. (2002). Governance and poverty in Pakistan. Pakistan institute of development economics, MIMAP technical series, No. 13.

Hobbes, T. (1651). Leviathan. New York: E. P. Dutton.

Hoff, K., \& Stiglitz, J. E. (2004). After the big bang? Obstacles to the emergence of the rule of law in postcommunist societies. The American Economic Review, 94(3), 753-763.

Islam, R., \& Montenegro, C. (2002). What Determines the Quality of Institutions? Policy research working paper series 2764, The World Bank.

Josifidis, K., Supic, N., \& Pucar, E. B. (2017). Institutional quality and income inequality in the advanced countries. Panoeconomicus, 62(2), 169-188.

Jutting, J. (2003). Institutions and development: A critical review. OECD development centre working papers 210, OECD Publishing.

Knack, S., \& Azfar, O. (2000). Are larger countries really more corrupt? Policy research working paper; No. 2470. World Bank, Washington, DC. https://openknowledge.worldbank.org/handle/10986/19757.

Knack, S., \& Keefer, P. (1995). Institutions and economic performance: Cross-country tests using alternative institutional measures. Economics and Politics, 7(3), 207-227.

Kotschy, R., \& Sunde, U. (2017). Democracy, inequality and institutional quality. European Economic Review, 91(C), 209-228.

La Porta, R., Lopez-de-Silanes, F., \& Shleifer, A. (2008). The economic consequences of legal origins. Journal of Economic Literature, 46(2), 285-332.

La Porta, R., Lopez-de-Silanes, F., Shleifer, A., \& Vishny, R. (1999). The quality of government. Journal of Law Economics and Organization, 15(1), 222-279.

Law, S. H., Tan, H. B., \& Azman-Saini, W. N. W. (2014). Financial development and income inequality at different levels of institutional quality. Emerging Markets Finance and Trade, 50(1), 21-33.

Levchenko, A. A. (2008). International Trade and Institutional Change. The Journal of Law, Economics, and Organization, 29(5), 1145-1181.

Moore, M. (2004). Revenues, state formation, and the quality of governance in developing countries. International Political Science Review, 25(3), 297-319.

North, D. C. (1990). Institutions, Institutional Change and Economic Performance. Cambridge: Cambridge University Press.

North, D. C. (1994). Institutions, institutional change, and economic performance. Cambridge: Cambridge University Press.

Rappaport, J. (1999). Local growth empirics. CID working paper 23. https://dx.doi.org/10.2139/ssrn.290596.

Redek, T., \& Susjan, A. (2005). The impact of institutions on economic growth: The case of transition economies. Journal of Economic Issues, 39(4), 995-1027.

Rigobon, R., \& Rodrik, D. (2004). Rule of law, democracy, openness, and income: estimating the interrelationships. NBER working paper no. 10750.

Rodrik, D., Subramanian, A., \& Trebbi, F. (2004). Institutions rule: The primacy of institutions over geography and integration in economic development. Journal of Economic Growth, 9(2), 131-165. 
Sokoloff, K. L., \& Engerman, S. L. (2000). Institutions, factors endowments, and path of development in the world. Journal of Economic Perspectives, 14(3), 217-232.

Sonin, K. (2003). Why the rich may prefer poor protection of property rights. Journal of Comparative Economics, 31, 715-731.

Straub, S. (2000). Empirical determinants of good institutions: Do we know anything? Inter-American Development Bank, working paper 423.

Tilly, C. (1992). Coercion, Capital and European States, AD 990-1992. Oxford: Blackwell.

Wade, R. (1990). Governing the market: Economic theory and the role of government in East Asian industrialization. Princeton: Princeton University Press.

World Bank. (2002). World development report 2002: Building institutions for markets. Oxford: Oxford University Press. 